\title{
Effect of Neighborhood Security on Housing Price in Lagos
}

\author{
Olalekan Dimeji Bamiteko ", Oyeyemi Omodadepo Adebiyi \\ Department of Economics, Faculty of Social Sciences, University of Lagos, Akoka, Nigeria \\ Email address: \\ olalekanbamiteko@gmail.com (O. D. Bamiteko), realyemmymeji@gmail.com (O. O. Adebiyi) \\ ${ }^{*}$ Corresponding author
}

To cite this article:

Olalekan Dimeji Bamiteko, Oyeyemi Omodadepo Adebiyi. Effect of Neighborhood Security on Housing Price in Lagos. American Journal of Environmental and Resource Economics. Vol. 5, No. 4, 2020, pp. 80-85. doi: 10.11648/j.ajere.20200504.11

Received: October 7, 2020; Accepted: October 27, 2020; Published: November 9, 2020

\begin{abstract}
Effect of neighborhood security on housing price in Lagos State Nigeria. The nonstop increase in urban population has created a gap between unceasing demand and limited supply of housing units in Nigeria particularly Lagos State. Housing being an heterogenous commodity has a lot of independent variables attached to it such as structural, location and neighborhood attributes (including crime rate). The population growth equally presented unemployment and insecurity in most neighborhood going by high rate of crime in Lagos State. The inadequate provision of security for life and properties by successive governments over the years along with population growth have caused unimaginably increase in crime rates in the city. The need for safety and prevention of crimes resulted into neighborhood security. The study confirms that the rate of crime in a particular neighborhood have a direct effect on housing price. This study investigates the effect of neighborhood security on housing price in Lagos State using Amuwo-Odofin Local government Area. The study employed primary data and surveyed 140 residents of the LGA through multistage sampling technique. Ordinary Least Squares (OLS) was used to analyze the data. The result, shows that fenced apartment, services of local securities and vigilantes and the presence of gateman have positive influence on price of housing in Lagos state. While high crime rates have a negative influence on housing price. The study concluded that residents pay higher housing price to live in a secured and crime free neighborhood. The study recommends the need for community policing is highly supported by the outcomes of this study.
\end{abstract}

Keywords: Housing, Neighborhood Security, Housing Price, Crime

\section{Introduction}

Neighborhood security is a product of government failure to provide adequate security; which is usually the case in most developing countries. The failure of government at all level to provide adequate security for life and property will automatically result into private alternatives to prevent crimes and eliminate the characteristics associated with ungoverned places. The crime rate in Nigeria has been increasing along with population growth overtime taking different dynamics. Similarly, there has been increase in the need for safety and the adaptation of different measures to prevent crimes as most megacities experience increase in urbanization due to population growth; Lagos inclusive [1]. The experience of urban cities in the need for safety and prevention of crime through the application of different method to control access could have semblance of medieval settlements where walls and trenches were applied to serve as barricades.

However, today's crime prevention and measures as it concerns residential area have taken different forms. There are variants in the measures adapted to prevent crime across different states in Nigeria. Furthermore, it varies within state, across local government areas and even streets as well as neighborhoods. Therefore, it means that neighborhood security takes its root from the medieval locally arranged forms of security where different measures were adapted to prevent crimes and control delinquencies in most neighborhoods. The neighborhood security has been increasing as crime rate increases and concern for safety increases as well. This situation has invariably transformed the urban townscape into segments of different neighborhoods with heterogeneous measures to prevent crimes and control movements through environmental and social designs [15]. The adapted social and environmental designs are most found in megacities due to growth in urban 
population and need to prevent the incessant increase in crimes will call for more creation of neighborhoods security. These measures are applied to prevent crimes ranging from the introduction of gates, fence, local vigilante and other crime preventions. The environmental and social designs adapted by most neighborhoods have been increasing due to urban population.

In Nigeria, Lagos is one of the megacities that have been identified as a city that represents phenomenon growth in urban population [5]. Lagos State is a cosmopolitan city where inflow of people has led to high rate of urban population with diverse characteristics. The population growth has resulted into shortage housing units due to the unceasing demand for housing units over limited supply; hence housing price becomes an issue of concern. The population growth equally presented unemployment and insecurity in most neighborhoods going by high rate of crime in Lagos. In year 2016, Lagos state was identified as one of the states with highest rate of crimes in Nigeria. ${ }^{1}$ Studies have examined the relationship between crime and residential area in developed countries $[27,16]$. In Nigeria, there are few studies $[14,17,18,24,26]$ that have considered the effect of crime and crime rate on property value in urban area and [2] examined patterns of violent crime in urban areas. Therefore, neighborhood security and housing price have so much to be considered in Lagos residential market; especially in Amuwo-Odofin, Local Government Area (LGA).

Residential market is where demand and supply of housing units take place. The continuous increase in urban population has created a gap between the unceasing demand for and limited supply of housing unit. In view of this, scarcity of housing is expected to take place and becomes an important commodity that requires household choice. Housing is one of the economic problems in a city like Lagos that has continued to be a center of attraction for many people from within and outside Nigeria [3]. Housing is not a homogenous commodity rather heterogeneous with a lot of independent variables attached to it, such as structural, location and neighborhood attributes (including crime rate). It is confirmed that the rate of crime in a particular neighborhood usually have a direct effect on housing price [13]. Hence this study investigates the effect of neighborhood security on housing price in Lagos state.

\section{Literature Review}

Studies on housing price and housing characteristics are voluminous particularly in the developed nations but such studies are sparse in case of the Africa continent in general and sub-Saharan Africa in particular. In Nigeria, however, there are few ones thus suggesting that a lot still needs to be done in order to bring it close if not at par with foreign counterparts.

The few ones that had been conducted in Nigeria to the best of our knowledge includes; [20] examined Jos

1 www.premiumtimesng.com -The 2016 National Bureau of Statistics Report. residential market; [8] estimated the effect of housing attributes in Ibadan, while [24] considered the effect of rental values in Ibadan, Oyo residential market; [22] used multiple regression analysis to study the significance of workplace locations in the residential location choice of residents of Ibadan. Equally, [23] showed the decision-makers in respect of the residential district in Ibadan. [28] investigated the determinants of households' residential district preferences within the metropolitan city of Ibadan. [19] analyzed Ogun State residential, Ewekoro precisely and [11] considered Akure residential market. While, [1, 4, 6, 9, 29, 30] considered Lagos residential market.

Megbolugbe applied Hedonic Pricing Model (HPM) on three categories of housing traits (structural, neighborhood and locational traits) to examine housing market in Jos, Nigeria [20]. He presented the results using Box-Cox $\lambda$ transformation parameter is 0.2 for the multi-family and- 0.1 for the single-family submarket. In his study the hedonic parameters of these functional forms are significantly different from linear functional forms and log-linear which usually available in literature. The author justified this position through comparison with similar studies conducted in other developed countries with results obtained.

Arimah estimated housing attributes in Ibadan, Nigeria using data from both tenants and owner-occupier [8]. The results identified income, household considerations, head of household occupational status and monetary value attached to the attributes being considered as important determinants in the demand for housing in Ibadan. The author concluded that since the coefficient of estimated variables are below unity then; the demand for housing qualities is inelastic.

Few studies applied HPM in Surulere and Ojota, Lagos Nigeria to examine the property value of housing based on proximity of units to urban solid waste and dumpsite $[10,25]$. These studies revealed that distance away and close distance presented higher value and lower values of properties respectively. Similarly, Bello et al considered residents' willingness to pay for environmental amenities in Akure, Nigeria [11]. The authors identified, distance away from refuse dump site along with household income and regularity of electricity supply as driving force towards households' willingness to pay for better environmental amenities. Akinjare et al used HPM to examine the impact of solid waste landfills on the value of housing units in Lagos residential market [7]. The results equally confirmed the deductions of [12] that proximity to environmental pollution is a key determinant on the value of property in Lagos, Nigeria.

Furthermore, studies like Aluko examined the effect of location and neighborhood characteristics on housing prices in Lagos residential market [6]. The study area was subdivided into 8 from the 16 metropolitan local government areas of Lagos, authors realized that location and neighborhood attributes are more significant on housing price, mostly when small housing units are being considered geographically. However, the author did not explain the rationale behind for using a sample size of 1500 out of a 
population of 135,820 in the study giving consideration to a bias judgment. Babawale et al employed HPM to examine the housing market in Ikeja, Lagos Nigeria [9]. Authors considered rental apartments, the sub-market under consideration and where plot size is unimportant. In their study, floor level was irrelevant, because the market did not cater for any price difference between flats on different floors, such as floors where 4 or even 5 exist. The age of building was excluded from the variables based on the fact that rental values (different from sale values) respond more to the physical condition than of the age of property age.

Oluseyi investigated the critical factors that influence the rental value of housing in Ibadan residential market, Nigeria [24]. The author applied HPM as the estimating tool to examine the influence of housing component (structural and location attributes) on housing price; The study revealed that for bungalow and detached houses in the low density area the key factor that influence rental value is residential location while in the medium density areas burglary alarm is the major determinant of house rental price.

Kemiki et al used the double log functional form of HPM to examine the effect of dust level and noise on rental value of dwelling apartments surrounding Lafarge Cement Factory in Ewekoro, Ogun State [19]. The authors in their finding discovered that noise and dust significantly affect rental prices of those houses around the factory negatively. The effect of noise and dust caused environmental discomforts that reduce prices of houses to $22 \%$ and $1.5 \%$ respectively depending on the proximity of any of houses to the factory. This also laid another premise for source of noise known as industrial noise.

More recently studies like Umeh and Oladejo identified the housing quality traits that influenced rents in Ikeja government residential area, Lagos [30]. The study revealed showed that neighborhood quality and number of bedrooms influenced house prices in the area considered. Also, the study equally supported that Waste disposal variables has a positive significant influence but not higher than the two other variables. Ajide used HPM to examine the impact of structural features on housing rent in Lagos, Nigeria [4]. The study revealed that hedonic pricing models consumer will prefer to pay more for desirable structural, locational and neighborhood traits in demand for housing units. However, this study suffers the dynamism of time where true picture of reality is lacking; the data used was based on the Lagos State Housing Survey of 2006 to analyze Lagos residential market in 2016. Residents in Lagos express their satisfactions and willingness to pay for housing units through choice making on housing attributes with respect to time $[1,12,29]$. Umar et al examined the residents' satisfaction level with public housing in Lagos, Nigeria. The study confirmed that there is still so much to do as regards housing issue in Lagos residential market. The authors discovered that majority of the residents are highly dissatisfied with space allocation, quality of services and infrastructural facilities. [29]. The Lagos residential market presents unique characteristics where both commodity and buyers are heterogeneous in nature.

\section{Data and Methodology}

\subsection{Conceptual Framework}

The conceptual framework for this research work can be explained through Figure 1 below. Population increase in urban centers, Lagos state inclusive would require government to increase provision of amenities and resources in order to play her roles. One of such roles is provision of adequate security for her citizens. Since government has failed to fulfill its role of provision of security, citizen have to come together to get it done. Hence, government failure led to neighborhood security. Also, increased population growth calls for increased demand and supply of housing units. As there is increase in quantity of houses, there is also necessity for neighborhood security. In addition, population growth can lead to increase in crime rate which in turn leads to need for neighborhood security. Neighborhood security itself comes with a cost, and the cost will be paid by the resident in the neighborhood. Therefore, the cost of the security in the neighborhood will reflect in the housing price; housing price will not just be the rent but rent plus the cost of making the house and the environment secured.

\subsection{Data and Sampling Technique}

Primary data was used by this study. The study area is Amuwo-Odofin LGA in Lagos State, Nigeria. The choice for Amuwo-Odofin LGA is borne out of the fact that in 2016, the crime rate across the country was analyzed by National Bureau of Statistics (NBS) and Lagos account for 36.08\% of crimes in Nigeria [31]. However, Amuwo-Odofin LGA crime rate was identified to be high compare to other local governments in 2018 despite the reduction in crime rate in Lagos by $55 \%$ [31].

This study adopts a survey method for residents of the LGA. Population of houses and households living in Amuwo-Odofin LGA is unknown; therefore, the sample size for this study is 150 through multistage sampling technique. A well-structured questionnaire was given to households resident in the streets selected; 50 questionnaires were administered in each street comprising of a total of 150 questionnaires. After controlling for incomplete questionnaires, 140 questionnaires were recovered and used for analysis in this study. 


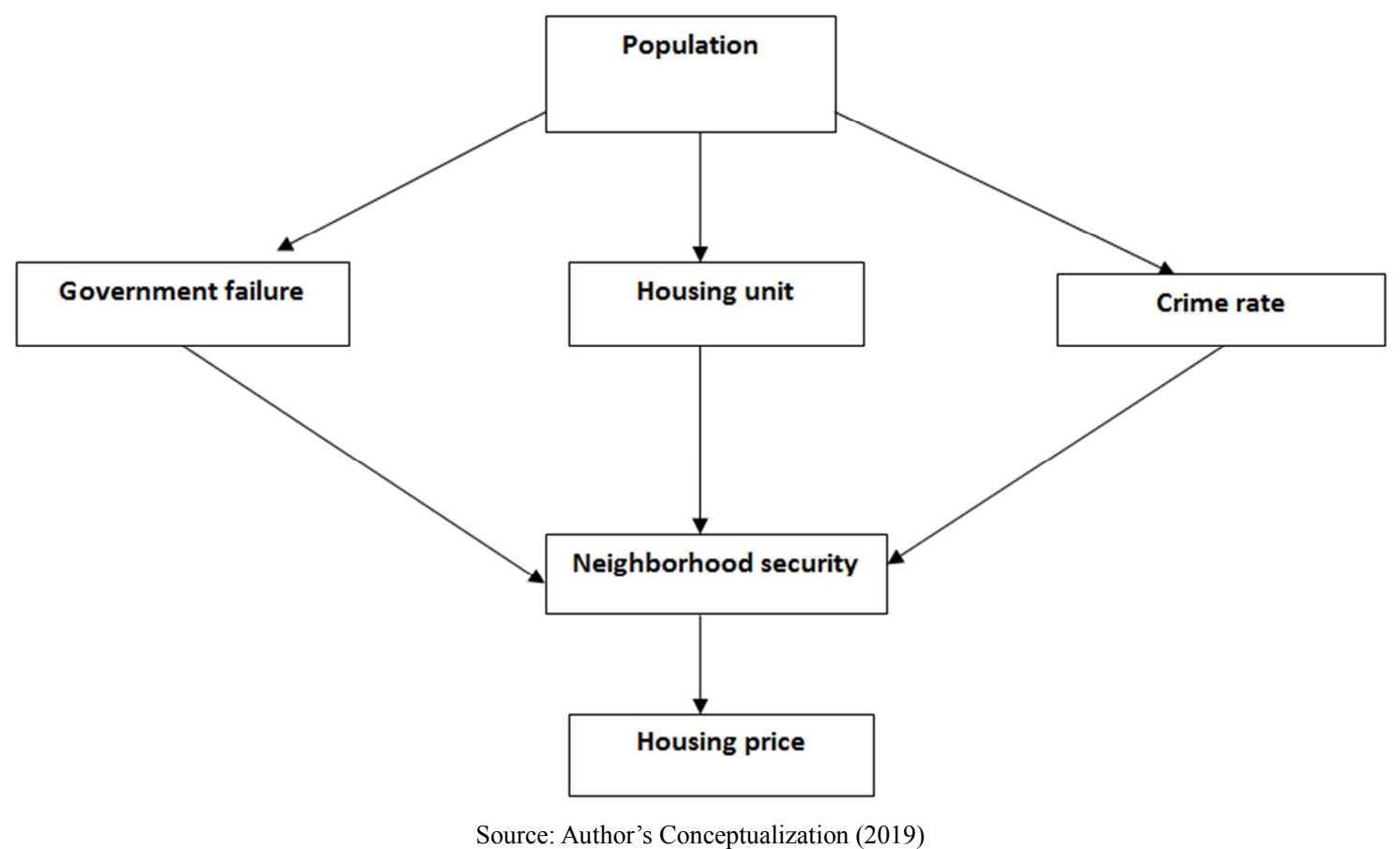

Figure 1. Conceptual Framework of Neighborhood Security and Housing Price.

\subsection{Estimation Technique and Model Specification}

The main objective of this study is to ascertain the effect of neighborhood security on housing price, was achieved using Ordinary Least Squares (OLS).

The OLS equation is specified thus:

$$
\begin{gathered}
H P=f(\text { FenC, ComG, CpoliS, Vigil, Gman, Crim }) \\
H P=a_{0}+a_{1} \text { FenC }+a_{2} \text { ComG }+a_{3} \text { CpoliS }+a_{4} \text { Vigil }+ \\
\left.a_{5} \text { Gman }+a_{6} \text { Crim }+\epsilon\right)
\end{gathered}
$$

Where, FenC is fenced apartment, $\operatorname{Com} G$ is community Gate, CpoliS is closeness to police or security agents, Vigil is the presence and effectiveness of vigilantes and local securities, Gman is the presence of gateman in the house/compound, Crim is crime rate in the neighborhood, $a_{0}$ is the intercept and $\epsilon$ is the error term. It is expected a priori that:

$$
a_{1}>0, a_{2}>0, a_{3}>0, a_{4}>0, a_{5}>0 \text { and } a_{6}<0
$$

\section{Result}

Effect of Neighborhood Security on Housing Price in Amuwo-Odofin, Local Government Area.

The result of the Ordinary Least Squares was displayed in Table 1 below. The coefficient of fenced apartment is positive and statistically significant at $5 \%$. This implies that housing price will be high in apartments that are fences. The better and more secured the fence; the higher will be the housing price in Lagos. This position follows our a priori expectation. Both community gate and nearness to police station or security outfit is positive but statistically insignificant. The direction of the coefficient indicates that community gate and nearness to security outfits have the ability of increasing housing price but the magnitude cannot be ascertained statistically. The service of vigilantes and local securities in Lagos is positive and statistically significant at 5\%; a unit increase in local securities will increase housing price about 0.11 units. This result is in conformity with our a priori expectation and the work of [21]. Since local securities are accessible and available to the residents of the community than the government securities; their effectiveness can increase their utility by making the residents secured, as a result, they must be well remunerated. Also, the residents feel more secured when vigilantes and local securities are present and effective, thereby they will be willing to pay for the utility they derive from these services. Hence, local securities and vigilantes will cause increase in housing price. The presence of gateman increases housing price in Lagos; the coefficient is positive and statistically significant at $5 \%$. Houses with gateman normally have fences and gates, thereby reducing access into the apartments. The service of gatemen is a determining factor which increases housing price in the state. Crime rate is negatively signed and statistically significant at $5 \%$; implying that neighborhood with high records of crime will have lower housing price. High crime rate in a neighborhood makes consumers feel unsecured and unwilling to live in the environment thereby causing them to be willing to pay less, hence, houses in the neighborhood attracts lower price. R-Square is 0.679 , indicating that about $70 \%$ variations in the housing price in Amuwo-Odofin LGA is being determined by the explanatory variables. F-Statistic is 879.363 , the implying overall significance of the model. Durbin Watson statistic is approximately 1.9 , close to 2 ; indicating that the model is free from serial autocorrelation. 
Table 1. Regression result.

\begin{tabular}{llll}
\hline Variables & Coefficient & T-Statistic & Probability \\
\hline Fenc & .216 & 3.824 & .000 \\
ComG & .096 & 1.490 & .625 \\
CpoliS & .034 & 1.008 & .993 \\
Vigil & .107 & 2.879 & .013 \\
Gman & .353 & 3.725 & .000 \\
Crim & -.039 & -2.625 & .021 \\
Durbin Watson=1.880 & R-Square $=0.697$ \\
F-Statistic=879.363 & F-Prob. $=0.000$ \\
Dependent Variable: Housing Price & & \\
\hline
\end{tabular}

Source: Author's computation (2019).

\section{Conclusion}

This study revealed clearly that the failure of government in the provision of adequate security for life and properties is a driving force behind the high consideration of neighborhood security and housing price in Amuwo Odofin Local Government Area, Lagos, Nigeria. From the result, fenced apartment, services of local securities and vigilantes and the presence of gateman have positive influence on price of housing in Lagos state. The fencing and presence of gateman being physical attributes present more psychological effect on tenants than other variables due to its explicit value in use and ease the need for immediate personal security attributes, which are highly considered by consumers of housing units as confirmed from the study. The services of local securities and vigilantes present another community independent security that confirms the aspect of housing consumers' participation in the provision of neighborhood security due to government's failure in the provision of adequate security for life and properties. While communities with high crime rates pay lesser rent. Therefore, residents pay higher housing price to live in a secured and crime free neighborhood. The study recommends the need for community policing is highly supported by the outcomes of this study.

\section{References}

[1] Afolayan, A. S., Nubi T. G. and Omirin., M. M. (2016). Appraising users' willingness to pay for improved housing in Lagos, Nigeria. Department of Estate $m$ Management, University of Lagos, Nigeria.

[2] Agbola, T. and Jinadu A. M. (1997). Forced eviction and forced relocation in Nigeria: the experience of those evicted from Maroko in 1990. Sage Journals Volume: 9 issue: 2, page (s): 271-288.

[3] Ajide K. B. (2011). Determinants of Residential Housing Choice in Lagos State, Nigeria: A thesis submitted to the Department of Economics, Faculty of the Social Sciences, University of Ibadan.

[4] Ajide K. B. (2016). A Hedonic Pricing model of the impact of housing structural features on House Rent in the Lagos Residential Property Market. Unilag Journal of Humanities 2016 - ujmt.unilag.edu.ng.
[5] Aluko, E. O. 2002, Housing values and determinants of housing submarkets in Nigeria, Journal of the Nigerian Institute of Town Planners, Vol. XVI, October, pp. 55-68.

[6] Aluko, O. (2011). The effects of location and neighborhood attributes on housing values in metropolitan Lagos. Ethiopian Journal of Environmental Studies and Management, 4 (2), 6982.

[7] Akinjare, O. A., Ayedun, C. A., Oluwatobi, A. O., \& Iroham, O. C. (2011). Impact of sanitary landfills on urban residential property value in Lagos State, Nigeria. Journal of Sustainable Development 4 (2): 48-60.

[8] Arimah, B. (1992). An empirical analysis of the demand for housing attributes in a Third World city. Land Economics, 68 (4), 366-79.

[9] Babawale, G. K., Koleoso, H. A., Otegbulu, A. C., (2012). A hedonic model for apartment rentals in Ikeja area of Lagos metropolis. Mediterr. J. Social Sci. 3 (3), 109-120.

[10] Bello, M. O. and Bello, V. A. (2007). The Influence of Consumer Behaviour on the Variables Determining Residential Property Values in Lagos, Nigeria. American Journal of Applied Sciences 4 (10): 774-778.

[11] Bello, M. O. and Bello, V. A. (2008). Willingness to Pay for Better Environmental Services: Evidence from the Nigerian Real Estate Market. Journal of African Real Estate Research, 1 (1), pp. 19-27.

[12] Bello, V. A., Ajayi, C. A., (2010). Occupants' satisfaction and rent paid for residential properties close to waste dump sites in Nigeria. J. Sustainable Dev. 3 (1), 98-103.

[13] Bello, V., (2011). "The impact of urban crime on property values in Akure, Nigeria", Paper presented at the FIG Working Week, 18-22 May. Marrakech, Morocco.

[14] Ekpenyong, R. A. (1989). Crime Prevention: Approaches, Practices, and Evaluations. Volume: 14 issue: 2, 200-202.

[15] Fabiyi, O (2004). Gated Neighbourhoods and privatization of urban security in Ibadan metropolis. New edition (online), Ibadan: IFRA-Nigeria, 2004 (generated 20 Jun 2019) Availiable on the Internet http://books.openedition.org/ifra/456>. ISBN: 9791092312027. DOI: $10.4000 /$ books.ifra456.

[16] Jargowsky, P. A., \& Park, Y. (2009). Cause or Consequence?: Suburbanization and Crime in U. S. Metropolitan Areas. Crime \& Delinquency, 55 (1), 28-50. https://doi.org/10.1177/0011128708323630.

[17] An assessment of the nature of urban growth and development in Akwa Ibom state, Nigeria.

[18] Robert Etim Ekpenyong Department of Geography and Natural Resources Management, University of Uyo, Nigeria robert_etim@yahoo.co.

[19] Kemiki, O. A., Ojetunde, I. and Ayoola, A. B. (2014). The Impact of Noise and Dust level on Rental Price of Residential Tenements around Lafarge Cement Factory in Ewekoro town, Nigeria. Ethiopian Journal of Environmental Studies and Management, 7 (2), 108-116.

[20] Megbolugbe, I. F. (1989). A Hedonic Index Model: The Housing Market of Jos, Nigeria. Sage Journals. 26 (5); 486494. 
[21] Odunjo O. O \& Odunola O. O. (2013). An Appraisal of House security Measures in Lagos, Nigeria. Architectural Research 3 (3); 21-25.

[22] Olatubara, C. O. (1996) Workplace factor in residential location choice in Ibadan, Nigeria, Ife Social Sciences Review 13 (1\&2): 50-62.

[23] Olatubara. C. O. 2003. Women participation of women in residential location decision-Making in Ibadan, Nigeria" Journal of the Nigerian Institute of Town Planners, Vol. XVI No. 1. pp 19-33.

[24] Oluseyi, J. O. (2014). Critical factors determining Rental Value of Residential Property in Ibadan Metropolis, Nigeria. Property Management, 32 (3), 224-240.

[25] Onifade, F. A. and Adewusi A. O. (2006). The effects of urban solid waste on physical environment and property transactions in Surulere Local Government Area of Lagos state. Journal of Landuse and Development Studies, 2 (1); 71-90.

[26] Otu, N. E. (2010). An Evaluation of the National Environmental Standards and Regulations Enforcement Agency (Establishment)
Act. A Paper Presented at the Abia State College of Postgraduate Studies, Faculty of Law, Nigeria.

[27] Sampson, R. J., Morenoff, J. D. and Earls, F. (1999) Beyond Social Capital: Spatial Dynamics of Collective Efficacy for Children. American Sociological Review Vol. 64, No. 5 633-660.

[28] Sanni, L. and Akinyemi, F. (2009). Determinants of Households' Residential Districts' Preferences within Metropolitan City of Ibadan, Nigeria. Journal of Human Ecology (Delhi, 25 (2): 137-141.

[29] Umar, O. S., Abdullahi O. O., Nathaniel O. O., Simeon O. F and Samuel, A. O. (2019). Residents' satisfaction with Public Housing in Lagos, Nigeria. Ghana journal of geography Voll1 (1) pages 180-200.

[30] Umeh, O., and Oladejo, E. (2015). Adopting the Hedonic Price of Residential Properties' Attributes to Improve Ikeja GRA in Lagos State Nigeria Environmental Review, 5 (1) Retrievedhttp://www.erjournal.net/index.php/erjournal/article/ view/8.

[31] https://nigeria.opendataforafrica.org/data\#source=NBS-N. 